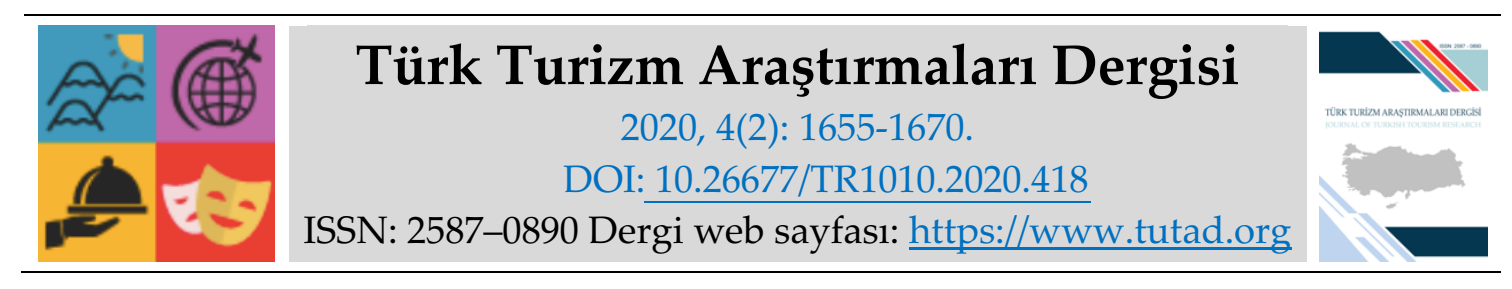

\title{
KAVRAMSAL MAKALE
}

\section{Turizm Sektöründe Sosyal Medya Kullanımı Üzerine Bir Değerlendirme}

Dr. Öğr. Üyesi Nurettin İMRE, Erzincan Binali Yıldırım Üniversitesi, Kemaliye Hacı Ali Akın Uygulamalı Bilimler Yüksekokulu, Erzincan, e-posta: nimre@erzincan.edu.tr

ORCID: https://orcid.org/0000-0002-1701-915X

\begin{abstract}
Öz
İnsanın insana hizmet ettiği bir sektör olan turizm, teknolojik gelişmelerin baş döndürücü hızına uyum sağlamaya çalışmaktadır. Bu konudaki önemli gelişmelerden birisi de işletmelerin internet tabanlı pazarlama stratejileri geliştirmeleri ve özellikle sosyal medyadan etkin bir biçimde yararlanmaya çalışmalarıdır. Turistik deneyimlerini sosyal medyada paylaşan ve bu mecradaki diğer kullanıcılarla etkileşim haline giren kişilerin tutum ve davranışlarının anlaşılması gerek turistik destinasyonlar gerekse bu destinasyonlardaki işletmelerin etkin pazarlama stratejileri açısından önem taşımaktadır. Bu önem, aynı zamanda turizm işletmelerinin sosyal medya araçlarını etkin kullanmalarını da zorunlu hale getirmiştir. Sosyal medyanın turist kararları üzerindeki etkisi ve öneminin değerlendirilmesinin amaçlandığı ve derleme niteliği taşıyan bu çalışmada; sosyal medyanın turizm sektörü için birçok avantaj sunmakla birlikte, denetim ve kontrol eksikliği nedeniyle bazı olumsuzlukları da beraberinde getirme ihtimalinin varlığına işaret edilmektedir. Turistik destinasyon ve turizm işletmelerinin sosyal medyayı etkin kullanabilmeleri, denetim ve kontrol faaliyetleri bakımından sosyal medya eğitimlerini de gerekli kılmaktadır.
\end{abstract}

Anahtar Kelimeler: Sosyal Medya, Pazarlama, Halkla İlişkiler, Turizm Sektörü.

Makale Gönderme Tarihi: 24.02.2020

Makale Kabul Tarihi: 12.04 .2020

\section{Önerilen Atıf:}

İmre, N. (2020). Turizm Sektöründe Sosyal Medya Kullanımı Üzerine Bir Değerlendirme, Türk Turizm Araştırmaları Dergisi, 4(2): 1655-1670.

(C) 2020 Türk Turizm Araştırmaları Dergisi. 


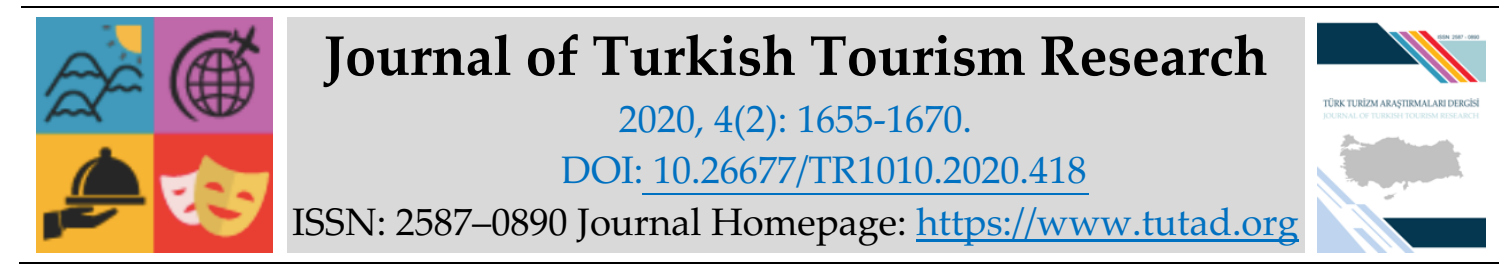

\title{
CONCEPTUAL PAPER
}

\section{An Evaluation of Using Social Media in Tourism Sector}

Assistant Prof. Dr. Nurettin IMRE, Erzincan Binali Yıldırım University, Kemaliye Hacı Ali Akın School of Applied Sciences, Erzincan, e-mail: nimre@erzincan.edu.tr

ORCID: https://orcid.org/0000-0002-1701-915X

\begin{abstract}
Tourism, which is a sector where people serve people, tries to adapt to the dizzying speed of technological developments. One of the important developments in this regard is that businesses develop internet-based marketing strategies and try to make effective use of social media in particular. Understanding the attitudes and behaviors of people who share their touristic experiences on social media and interact with other users in this media is important in terms of effective marketing strategies of both touristic destinations and businesses in these destinations. This importance also made it compulsory for tourism companies to use social media effectively. In this study, which aims to evaluate the impact and importance of social media on tourist decisions and is a compilation; although social media offers many advantages for the tourism sector, it is pointed out that there is a possibility of bringing some negativities due to lack of control and control. The fact that touristic destinations and tourism enterprises can use social media effectively also requires social media training in terms of inspection and control activities.
\end{abstract}

Keywords: Social Media, Marketing, Public Relations, Tourism Sector.

Received: 24.02 .2020

Accepted: 12.04 .2020

\section{Suggested Citation:}

İmre, N. (2020). An Evaluation of Using Social Media in Tourism Sector, Journal of Turkish Tourism Research, 4(2): 1655-1670.

(C) 2020 Türk Turizm Araştırmaları Dergisi. 


\section{Gíriş}

Teknoloji tarihine bakıldığında, buluşlar ile toplumsal değişim arasında bir paralellik ve etkileşim olduğu görülmektedir. Teknolojik gelişmelere bağlı olarak insanların kültürleri, toplumsal örgütlenme biçimleri kurumsal ortamlar değişmektedir. Teknolojinin bu gelişimi ve küreselleşme, iş ve sosyal yaşamda büyük değişikliklere sebep olmuştur. İnternet ve bilgisayar ağlarının hızlı bir şekilde günlük yaşama girmesiyle "bilgi çağı" olarak adlandırılan bir dönem başlamıştır. Bununla beraber yeni medya teknolojileri, insanlara düşüncelerini, yaşam tarzlarını ve üretimlerini paylaşacakları imkânları yaratan, paylaşım ve tartışmanın temel alındığı bir medya sunmaktadır ki, o da sosyal medya olarak adlandırılmaktadır (Akıncı Vural ve Bat, 2010: 3348). Sosyal medyanın, hayatın her alanına nüfuz etmesiyle beraber, işletmelerde de kullanımı kaçınılmaz olmuştur. Dolayısıyla sosyal medyanın turizm sektörü açısından önemini de göz önünde tutmak gerekmektedir.

Son yıllarda bireylerin yeni iletişim araçlarını gündemi takip etmek ve bilgilerini güncel tutmak için aktif bir şekilde kullandığı; işletmelerin de maliyet ve daha fazla hedef kitleye ulaşma gibi fırsatlardan yararlanmak amacıyla yeni teknolojilere yoğunlaştıkları dikkat çekmektedir. Teknoloji ilerledikçe, bunun bir sonucu olarak yeni sosyal medya uygulamalarının da hızla ortaya çıktığı gözlenmektedir.

Sosyal medya uygulamaları sayesinde işletmeler; müşteri ilişkileri, satış geliştirme, reklam gibi faaliyetlerini düşük maliyetle daha geniş kitlelere iletebilmektedirler. Gerek işletmelere gerekse tüketicilere sağladığı kolaylıklar nedeniyle, sosyal medya kullanıcı sayısı ve kullanım süreleri artmaktadır.

Bu çalışmada sosyal medyanın turist kararları üzerindeki etkisi ve turizm sektörü için öneminin ortaya konulması amaçlanmıştır. Çalışma nitel araştırma türünde olup, konuyla ilgili alanyazın ve sosyal medya kaynaklarından elde edilen veriler kullanılarak; sosyal medyanın tarihsel gelişim süreci, sosyal medyanın işletmelerdeki kullanım alanları ve sosyal medyanın turizm sektörü için önemi değerlendirilmiştir. Bunun için ilk olarak turist kararlarında sosyal medyanın etkisi ele alınmıs, ardından turizm işletmelerinde sosyal medya kullanımının önemi değerlendirilmiştir.

\section{SOSYAL MEDYANIN GELISŞIM SÜRECİ VE ÖNEMI}

1990'lardan itibaren gündelik yaşam içerisinde hızlı bir şekilde yayılmaya başlayan internet ve bilgisayar ağları dünyayı küçültürken "Küresel köy", "Sanayi sonrası toplum", "Bilgi çağı" ve "Üçüncü dalga" gibi yeni kavramları da gündeme getirmektedir. İçinde bulunulan çağda "iletişim" teknolojileri sayesinde bilgi hızla çok geniş kitlelere ulaşabilmekte, böylelikle toplumların ortak değerler etrafında birbirlerine yaklaşma süreci hızlanmaktadır. İnternet, kapitalist ülkelerin ciddi bunalım içinde olduğu 1970 ve 1980'li yılların ertesinde gündeme gelmiş̧ir. Baş döndürücü bir hızla büyüyen internet, bulunuşundan otuz, ticari kullanımından yedi yıl sonra $\mathrm{ABD}^{\prime}$ de nüfusun yüzde ellisi tarafından kullanılır hale gelmiştir (Güçdemir, 2017:3). Bununla birlikte "yeni medya" kavramı da 1980'lerin sonundan itibaren insan hayatına giriş yapmış ve yayımcılıktan, televizyonculuğa, fotoğrafçılıktan telekomünikasyona kadar hemen her alanda kullanılmaya başlamıştır. Bu süreç kültürel etkileşimlerin artması dolayısıyla kültürel değişimlere sebep olurken, aynı zamanda küreselleşme süreçlerinin hızlanmasına ve yaygınlaşmasına da sebep olmuştur (Özgen, 2011: 92-93). Etki ve sonuçlarıyla yeni bir dünyayı ifade eden yeni medya kavramı; gelişen bilgisayar ve internet teknolojisiyle ortaya çıkan ve mobil teknolojisiyle hızla yaygınlaşan, kullanıcıların hem zamandan hem de mekândan bağımsız olarak interaktif bir şekilde etkileşimde bulundukları sanal medya ortamı olarak 
tanımlanabilir (Bulunmaz, 2014: 25).

Yeni medya ile birlikte mesajlar, kişiler ve gruplar bazında seçilebilmekte ya da adreslenebilmektedir, dolayısıyla insan aklıyla karşılaştırılamayacak oranda büyük bir bellek kapasitesine sahip olan bir iletişim biçimi ortaya çıkmış, böylece de iletişimde, coğrafi ve demografik faktörlerin önüne geçilerek uzak mesafelerin sorun olması ortadan kalkmıştır (Törenli, 2005: 155-156'dan aktaran Balcı vd., 2013: 7). Bu nedenle yeni medyanın gelişimini değerlendirirken teknolojik faktörler dışındaki konuların da göz önünde tutulması gerekmektedir. Yeni medya olanaklarını sunanların, okurları ve izleyicilerinin iletişim temelinde kişisel ve toplumsal gereksinimlerini ne ölçüde karşıladıklarına ve bu faktörlere bağlı olarak ne kadar esnek olabileceklerine de bağlıdır (Tiryaki, 2015, 107).

Yeni medyanın gelişimi, sosyal paylaşım ağlarının ortaya çıkmasını sağlamış ve sanal dünya ile reel (gerçek) dünya ayrımı ortadan kalkmıştır (Kırık, 2017: 242). Sosyal medya olarak adlandırılan bu sanal dünya, bireysel kullanıcı tabanlı olmakla birlikte, büyük insan kitlelerini bir araya getirmekte ve aralarındaki etkileşimi arttırmaktadır (Akıncı Vural ve Bat, 2010: 3348). Sosyal medya, insanların fikirlerini kolaylıkla paylaştı̆̆ı, ilgili olsun veya olmasın her konuda yorum yapabildiği ve başkalarının fikir ve tavsiyelerini görebildiği bir platform olarak insan yaşamında önemli bir yer edinmiştir. İnsanlar, sosyal çevrelerini genişletme, duygu ve düşüncelerini dile getirme, deneyimlerini paylaşabilme ve kitlelere ulaşabilme amacıyla bu araçları kullanmaktadır (Vardarlıer, 2016: 1). Sosyal medya kişi, grup ve örgüt gibi toplumsal birimler arasında bilgi alışverişi oluşturabilmekte, kullanıcılara enformasyon, düşünce ve bilgi paylaşımı imkânı sağlamakta ve birey sosyal medyada içerik oluşturabilmektedir (Sabuncuoğlu ve Gümüş, 2008: 9; Sayımer, 2008: 128; Scott, 2010: 38). Yapılan araştırmalara göre insanlar, bu sanal dünyada daha fazla vakit geçirmekte, sosyal ihtiyaçlarını karşılamaya çalışmakta ve hatta kendilerine bu dünya içinde yeni bir dünya kurarak yaşamaktadırlar veya bu dünyadan tanıştığı kişilerle evlilik gibi ciddi kararları bile alabilmektedirler. Sosyal medya, özellikle gençler arasında kullanım trendi hızla yükseldiği için, geleneksel medyaya rakip olmuş ve hatta çoğu zaman geleneksel medyayı tehdit eder duruma gelmiştir (Akıncı Vural ve Bat, 2010: 3348).

Geleneksel medya üç büyüğü (yasama, yürütme ve yarg1) kontrol eden dördüncü kuvvet olarak bilinirken, sosyal medya ise kamuoyunu, devlet organlarını veya hükümeti kontrol eden ve genellikle bağımsız hareket edebilen bir oluşum olarak ortaya çıkmaktadır (Erdoğan, 2013:177). Günümüzde yeni medya ve onun bir parçası olan sosyal medya gündem oluşturmak için yeni yollar açmıştır. Bu noktada bloglardan, bilgi açısından zengin sivil toplum kuruluşu (STK) ağlarına, kalabalık ve yoğun Twitter akışlarına kadar çeşitli çevrimiçi kanalların artmasıyla geleneksel medyanın görmezden gelemeyeceği bir ortam söz konusudur (Pfetsch vd., 2013: 11).

\section{Dünyada ve Türkiye'de Sosyal Medyanın Kullanımı}

Web tabanlı uygulamalarla, sosyal medya araçlarının gün geçtikçe kullanımı artmaktadır. We Are Social ve Hootsuite'in Ocak 2020'de yayınladığ 1 "Digital 2020: Global Digital Overview" raporuna göre dünya nüfusunun $\% 59^{\prime} \mathrm{u}$, yaklaşık olarak 4,54 milyar insan, internet kullanıcısıdır. Diğer taraftan dünyada toplam internet kullanıcılarının \%92'si, bir başka ifade ile 4,18 milyon kişi ise, mobil internet kullanıcısıdır (Datareportal1, 2020). 2015-2020 yılları arasında internet kullanıcılarının dünya nüfusuna oranı Şekil 1.'de görüldüğü gibidir. 


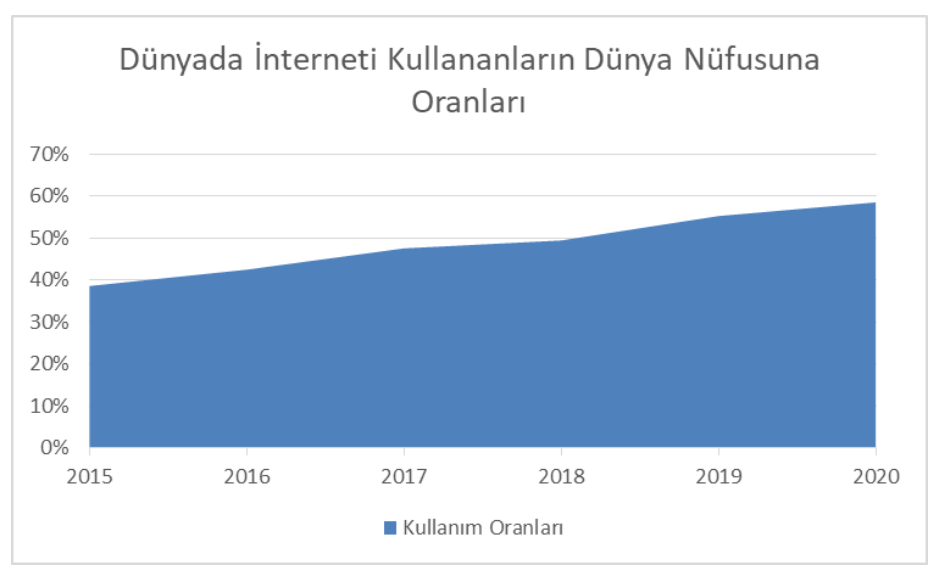

Şekil 1. Yıllara Göre Dünyada İnternet Kullanım Oranları

Kaynak: WPR 1 ve Datareportal 1 verilerinden yararlanılarak oluşturulmuştur.

Diğer taraftan dünyada 14-64 yaş arası nüfus ortalama olarak günlük 6 saat 43 dakikalarını internet kullanımıyla geçirirken, bu sürenin ortalama 3 saat 22 dakikası mobil cihazlardan internet kullanımıyla geçirilmektedir. Aynı yaş grubunun sosyal medyada geçirdiği süre ise, ortalama 2 saat 24 dakikadır. Yine aynı rapora göre, Ocak 2020'de dünya nüfusunun $\% 49^{\prime}$ u, yani yaklaşık olarak 3,80 milyar insan, aktif sosyal medya kullanıcısıdır. 13 yaş üstü dünya nüfusunun ise $\% 63$ 'ü aktif sosyal medya kullanıcısıdır. Sosyal medya kullanıcılarının \%99'u, yani 3,75 milyar insan, sosyal medya sitelerine mobil cihazlarından erişim sağlamaktadır. Sosyal medya kullanım oranlarl, Şekil 2.'de görüldüğü gibi, 2015-2020 yıllarında internet kullanım oranlarına paralel bir şekilde artış göstermektedir (Datareportalı, 2020).

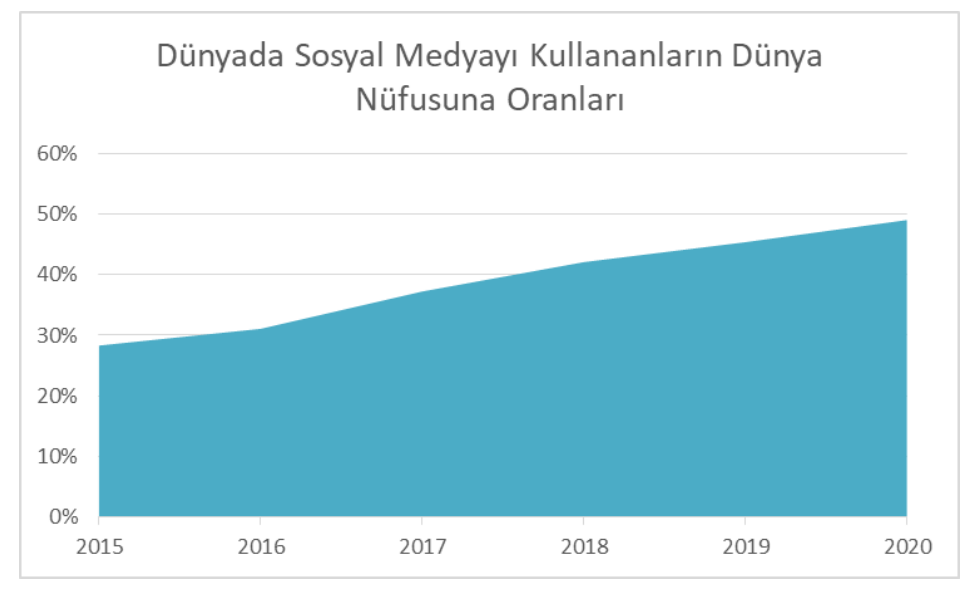

Şekil 2. Yıllara Göre Dünyada Sosyal Medya Kullanım Oranları

Kaynak: WPR 1 ve Datareportalı verilerinden yararlanılarak oluşturulmuştur.

Dünyada her bir internet kullanıcısı başına ortalama 8,6 sosyal medya hesabı bulunmaktadır. Dünyada en çok ziyaret edilen sosyal medya siteleri ise, sirasiyla Facebook, Youtube, Whatsapp, FB Messenger, Wechat, Instagram, Douyın/Tiktok, QQ, Qzone, Sna Weibo, Reddit, Snapchat, Twitter, Pinterest'tir.

Türkiye İstatistik Kurumu (TUIK) verilerine göre, Türkiye'de internet kullanıcılarının sayısı, dünyada olduğu gibi, her geçen yıl hızla artmaktadır. Şekil 3.'de 2007-2019 yılları arasında internet kullanıcılarının toplam nüfusa oranı görülmektedir (TUIK, 2020). 


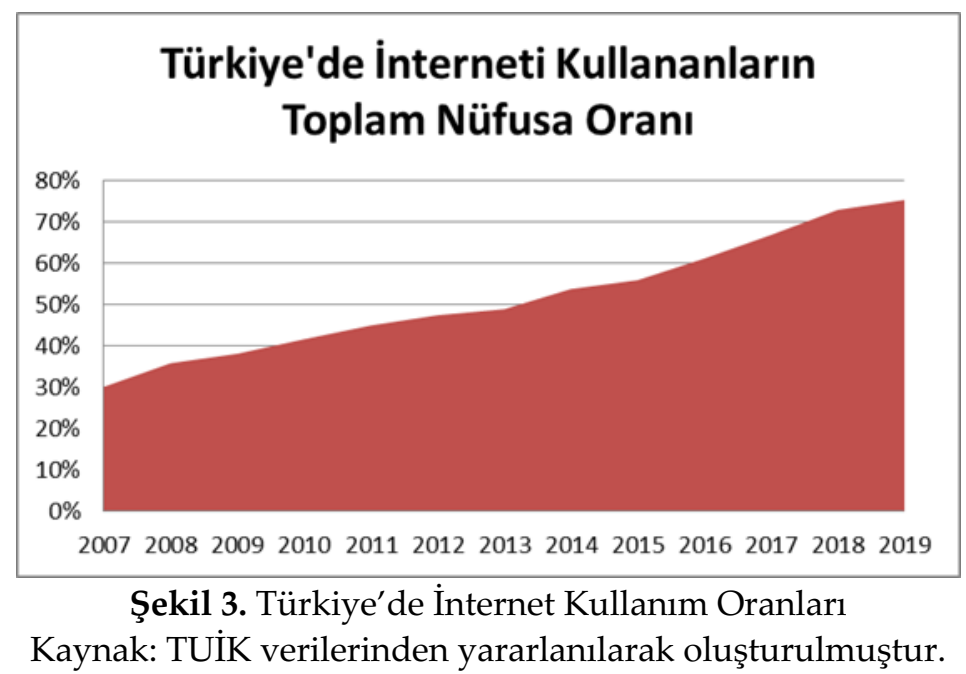

Yine We Are Social ve Hootsuite'in Ocak 2020'de yayınladığ 1 “Digital 2020: Turkey" raporuna göre, Ocak 2020'de Türkiye nüfusunun \%74'ü (yaklaşık 62 milyon 77 bin kişi) internet kullanıcısıdır. Türkiye'de 16-64 yaş aralığında bulunanların internet kullanarak geçirdikleri süre ise ortalama 7 saat 29 dakikadır. Aynı yaş grubundaki insanların mobil cihazlardan internet kullanım süresi ise ortalama 4 saattir. Ocak 2020 verilerine göre, Türkiye nüfusunun \%64'ü, yani 53 milyon 688 bin kişi, aktif olarak sosyal medyayı kullanmaktadır. Diğer taraftan 13 yaş üstü nüfusun ise \%81'i sosyal medyayı aktif olarak kullanmaktadır. Türkiye'de 13-64 yaş grubunda her bir internet kullanıcısının ortalama 9,1 aktif sosyal medya hesabı bulunmaktadır. Türkiye'deki internet kullanıcılarının en çok kullandığı sosyal medya platformları ise sırasıyla; Youtube, Instagram, Whatsapp, Facebook, Twitter, FB Messenger ve diğerleridir (Datareportal2, 2020; WPR2, 2020).

Tüm bu veriler gerek Türkiye'de gerekse dünyada internet kullanıcilarının toplam nüfusa oranının her yıl arttığını ve bu artışın zaman içerisinde süreceğini göstermektedir. Bu artışın; kullanıcı sayıları, kullanım amaçları, kullanım süreleri ve yaş grupları açısından izlenmesi önem arz etmektedir. Sosyal medya araçlarının internet kullanımındaki yerinin ve bu konudaki değişimlerin izlenmesi, işletme faaliyetleriyle ilgili stratejilere etki edebilecektir.

\section{İŞLETMELERDE SOSYAL MEDYANIN KULLANIM ALANLARI}

Sosyal ağlar, sosyal ve ekonomik ilişkilerin katlanarak artmasını sağlayabilmektedir (Cote ve Pybus, 2007: 95). 21. yüzyılda sosyal medya yönetimi iş dünyasının ayrılmaz bir unsuru olmuştur. Sosyal medyanın pazarlama bağlamındaki rolünün anlaşılması araştırmacılar ve yöneticiler için kritik öneme sahiptir. Bu konuda yapılmış mevcut çalışmalar ise, satın alma davranışı, müşteri ilişkileri yönetimi, marka yönetimi, yenilik yönetimi ve çalışanların işe alımı gibi belirli konulara odaklanmaktır (Felix vd., 2016: 118). Sosyal medya, İşletmeden işletmeye (B2B - Business to Business), İşletmeden tüketiciye (B2C - Business to consumer), Müşteriden müşteriye (C2C), Müşteriden işletmeye (C2B - Consumer to business) gibi e-ticaret uygulamaları ve kurum içi iletişim için yüksek etkinlikte bir araçlar bütünüdür. Sosyal medya araçlarının en önemli özelliği küresel çapta sınırları ortadan kaldırmak ve kendi kitlelerini oluşturmaktır (Varol, 2017: 400). Bu platformlarda oluşan topluluklar birbirini etkilemekte, bilgiyi yaymakta ve internette kendilerine özel alanlar yaratmaktadır. Kurumlar açısından internet ve sosyal medyanın gücü gün geçtikçe artmaktadır. Özellikle sosyal medya araçları, kuruluşların örgütsel gelişimine, hedef kitlelerine sürekli ulaşabilmelerine destek vermektedir. Sosyal medya kurumların hedef kitleleri ile iletişim kurabileceği birçok yeni yol açmıştır. Aynı 
zamanda tedarikçi ilişkilerini, müşteri ilişkilerini ve diğer paydaşlarla diyaloglarını aktif bir şekilde kolaylaştırır. Buna ek olarak, sosyal medya, müşterilere kendi düşünce ve fikirlerini açıklamaya izin vermektedir. Bu nedenle sosyal medya araçları, kurumların ürünler ve hizmetler hakkında hedef kitlelerin farkındalığını ve anlayışını artırmaya yardımcı olan mecra olarak ortaya çıkmaktadır (Çalışkan ve Mencik, 2015: 255).

Sosyal medya, işletmelerin hedef kitleleriyle, geleneksel iletişim araçlarına nispeten daha düşük maliyetle ve daha yüksek verimlilik seviyelerinde iletişim kurmalarına izin vermektedir. Sosyal medyanın yoğun kullanıcı kitlelerine sahip olması, hızlı bir şekilde gelişen reklâm, mesaj iletme ve iletişim davranışları, iletilmeye çalışılan mesajların her gün/saat/dakika/saniye boyunca birbiriyle ve hedef kitleyle yarışır durumda olması, bilgi akışının hızlı olması ve görece eskiyen mesajların önemsenmemesi gibi durumlar, hedef kitlenin dikkatini çekmeyi ve ona ulaşmayı zorlaştırabilir. Bu nedenle sosyal medya için başarılı bir iletişim stratejisinin belirlenmesi, rekabet sürecinde ayırt edilebilir olmayı sağlayacaktır (Királ’ová ve Pavlíčeka, 2015: 359-360). Nitekim sosyal medya, kurumlar için etkin iletişim ve hızlı geri bildirim gibi yarattı̆̆ fırsatların yanında, bazı olumsuzluklar ve riskler de barındırmaktadır. İleti akışları iyi yönetilemezse kurumun itibarına zarar verilebilir. Zira hedef kitle etkinliğinin artırılmasıyla geri bildirimlerin daha eleştirel ve acımasız olması riski ile karşı karşıya kalınabilir (Tekvar, 2012: 99).

Kuruluşlar hedef kitlelerini, kampanyalarından, hizmetlerinden ve ürünlerinden, haberdar edebilmek için sosyal medya araçlarını alternatif kanallar olarak görmektedirler. Dünyada ve ülkemizde milyonlarca kişinin Facebook, Twitter gibi sosyal ağlara olan ilgisi kuruluşları yeni stratejiler geliştirmeye zorlamaktadır. Sosyal medya bir taraftan kuruluşların hedef kitlelerini genişletirken diğer taraftan hedef kitleleri birbirleriyle daha önce hiç olmadığı kadar yakınlaştırmaktadır. Sosyal paydaşların büyük çoğunluğunun (tüketiciler, iş ortakları, bayiler) bu mecrada yer alması, kuruluşların pazarlama ve iletişim stratejilerini bu yöne kaydırmaktadır. Sosyal medya, kuruluşların doğrudan hedef kitleleri ile iletişim kurabildikleri, onların yorum, eleştiri ve beklentilerini elde edebildiği en etkili mecralarıdır (www.cdnacikogretim.istanbul.edu.tr).

\section{Pazarlama ve Sosyal Medya}

Sosyal medya araçlarının oluşturduğu ortamların, işletmelerin pazarlama stratejilerinde ciddi ve önemli bir potansiyel güç oluşturduğu söylenebilir. Facebook, Twitter gibi sosyal ağ siteleri büyük bir pazar ortamı sağlarken, sosyal ağlardaki kullanıcılar ve bu kullanıcıların kişisel tüketici alanları, profilleri, bağlantıları ve yorumları da hedef kitlenin taleplerinin daha kolay belirlenmesini sağlamaktadır. Sosyal medya üzerinden yürütülen pazarlama uygulamaları bir satış yöntemi değil, satış artışı sağlayan stratejik bir iletişim süreci olarak ortaya çıkmaktadır (Güçdemir, 2017: 99). Bu durumun, "sosyal medya pazarlaması" olarak literatürde yer bulduğu açıktır.

Akar (2010: 33)'a göre, sosyal medya pazarlaması, sadece en son jargonlardan biri olmaktan daha fazlasını ifade etmektedir. Geçmişte internet, "ben, benim ve kendim” ile ilgiliyken; geçen birkaç yılda önemli bir şekilde değişmiş ve on-line etkileşimler günümüzde daha sosyal hale gelmiştir. Sosyal medya pazarlaması ise sözü edilen bu on-line etkileşimlerin kaynağını oluşturan sosyal medya sitelerini kullanarak, internet üzerinden görünürlüğü arttırmak, üretilen mal ve hizmetlere yönelik tutundurma faaliyetlerini yaygınlaştırmak olarak tanımlanabilir (Özgen ve Doymuş, 2013: 95).

Sosyal medya pazarlaması 3 temele dayanmaktadır. Bunlar; sosyallik, medya (iletişim ve araçlar) ve pazarlama olmak üzere üç bileşenden oluşmaktadır. Aslında sosyal medya 
pazarlaması, toplulukları dinleme ve aynen karşılık vermeyle ilgili olsa da çoğu sosyal medya pazarlamacısı için içeriği gözden geçirmeyle ya da özellikle yararlı içeriği bulmak ve internetin geniş sosyal alanında bu içeriğin teşvik edilmesi ile ilgilidir (Erkan, 2010: 34).

Sosyal medya pazarlaması ile marka farkındalığı yaratılabilir, tüketici davranışları incelenebilir, yeni pazarlama stratejileri için fikirler geliştirilebilir, kurumun e-ticaret sitesine yönlendirme yapılabilir, spesifik mesajlar viral olarak yaygınlaştırılabilir, marka mesajının teşhir süresi uzatılabilir, markanın itibar ve imajı arttırılabilir ve hedef kitle tarafından içselleştirilmesi sağlanabilir, ürün satışları arttırılabilir, pazarlama amaçlarına etkili bir şekilde ulaşma sağlanabilir (Özgen ve Doymuş, 2013: 96)

Sosyal medya pazarlaması ile geleneksel pazarlama arasındaki farklar Tablo 1'de görülmektedir.

Tablo 1. Sosyal Medya Pazarlaması ve Geleneksel Pazarlama Farklılıkları

\begin{tabular}{|l|l|l|}
\hline & Geleneksel Pazarlama & Sosyal Pazarlama \\
\hline Maliyet & Yüksek & Düşük \\
\hline $\begin{array}{l}\text { Zamanıf Kitleye Ulaşma } \\
\text { Ulaşılabilen Müşteri Sayısı }\end{array}$ & Sinırlı - Belirlenen zamanlarda & Sınırsız \\
\hline İletişim & $\begin{array}{l}\text { Kaynaktan alıcıya } \\
\text { (Alıcı Pasif) }\end{array}$ & $\begin{array}{l}\text { Kahnaktan alıcıya } \\
\text { (Alıcı Aktif - yorum yapar, soru } \\
\text { sorar, paylaşır) }\end{array}$ \\
\hline Kampanya Zamanı & $\begin{array}{l}\text { Kampanya kurgusu uzundur. } \\
\text { Düzeltme süreci uzun ve } \\
\text { maliyetlidir. }\end{array}$ & $\begin{array}{l}\text { Kampanya kurgusu kolaylıkla } \\
\text { yenilenebilir, anı yakalayan } \\
\text { paylaşımlarla dikkat çekilebilir. }\end{array}$ \\
\hline Tüketici İletişimi & $\begin{array}{l}\text { Müşteri ile kurum arasında } \\
\text { bireysel iletişim. (e-mail, } \\
\text { mektup, telefon vb.) }\end{array}$ & Kamuya açık iletişim. \\
\hline Deneyim ve Zenginlik & $\begin{array}{l}\text { Belirli kalıplara uymayı } \\
\text { gerektirir. }\end{array}$ & Farklı deneyimlemelere açıktır. \\
\hline Kurum Departmanları & $\begin{array}{l}\text { Halkla İlişkiler, Pazarlama vb. } \\
\text { Resmi, mesafeli }\end{array}$ & $\begin{array}{l}\text { Sosyal Medya Bölümü, Dijital } \\
\text { Pazarlama Departmanı vb. }\end{array}$ \\
\hline İletişim Dili & Demografiye göre & Samimi, sıcak \\
\hline Pazar Bölümlendirmesi Tutum ve Davranışa göre \\
\hline Kayna
\end{tabular}

Kaynak: www.digitalpazarlamaokulu.com verilerinden yararlanılarak yazar tarafından oluşturulmuştur.

Sosyal medya pazarlama döngüsü Şekil 4'de görülmektedir. Kuruluşlar sosyal medya pazarlama stratejilerini belirlerken bu döngüyü göz önünde bulundurmalıdır ( $\mathrm{O}^{\prime}$ Brien ve Terschluse, 2009: 4-10); 


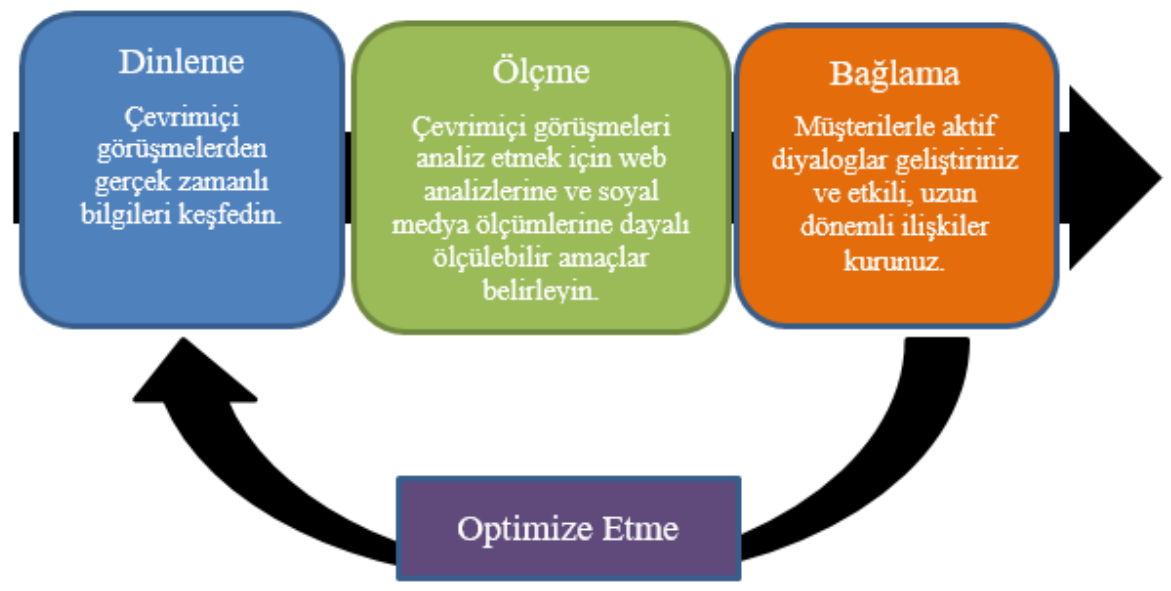

Şekil 4. Sosyal Medya Pazarlama Döngüsü

Kaynak: O'Brien ve Terschluse, 2009: 4

Dinleme: Sosyal medya platformlarında üyeler diğer her şey gibi kurumlar, markalar ve ürünler hakkında da çeşitli yorumlar yapmaktadırlar. Bu ortam işletmelere yüksek maliyetli anketler ya da benzeri araştırmalar yapmadan hedef kitlenin tercihlerinin hangi yönde şekillendiği konusunda çeşitli avantajlar sağlar. Diğer taraftan müşteriler ürün ya da markaya yönelik beğeni ve şikâyetlerini de bu platformlarda dile getirebilirler. İşletmeler müşteriyi dinleyip, bu şikâyetlere çözüm ürettikleri sürece ürün ve marka bağımlılığı oluşturabilirler.

Ölçme: Sosyal medyada pazar etkileşimin çıtılar açısından değerlendirilmesi ve ölçülebilmesi gerekmektedir. Sosyal medya analizleriyle beğeni sayısı, takipçi sayısı, öneri oranı, yönlendirme oranı gibi ölçülebilir verilerle sosyal medya analizleri ve tıklama oranı, sıçrama oranı, siteyi ziyaret eden insan sayısı, sayfa görüntüleme uzunluğu gibi ölçülebilir verilerle web analizleri yapılabilir ve ardından bunların satışlar ve pazar payları üzerindeki etkileri ölçülebilir.

Bağlanma: Sosyal medyanın nicel ve nitel veriler üzerinden etkin analizi sonrasında elde edilen verilerle, pazarlamacının sosyal medya katılımcılarını bölümlere ayırmasını olanaklı kılar. Pazarlamacılar onları marka savunucuları, pasifler ya da marka aleyhine konuşanlar gibi genel eğilimlerine göre sınıflandırabilirler. Böylece katılımcılarda nasıl ve nerede etkileşim kurup, bağlılık sağlayacağına ilişkin yol haritası oluşturabilirler. Sosyal medya platformundaki etkin ve önemli üyeleri tanımlayarak, bağlılık stratejisi için temas noktası oluşturabilirler.

\section{Sosyal Medya, Reklâm ve Halkla İlişkiler}

Sosyal medya üzerinden reklamcllık uygulamaları kısa bir süre içinde benimsenmiş ve mecra olarak kullanım oranı artmıştır. Geleneksel mecralarda reklamcılık tek yönlüdür. Sosyal medyada ise reklam tüketiciye "bir şeyler söylemekten" çok onunla "sohbet etmeye" dönüşmüştür. Sosyal medyanın bu denli gelişmesi, geleneksel reklam mecralarına karşı bazı üstünlükleri olduğunun göstergesidir. Geleneksel mecralarda kullanılacak bir reklamin hazırlanması belli bir dönem sürerken, sosyal medya üzerinden verilen reklam, anında yayınlanabilir ve üzerinde değişiklikler yapılabilir.

Sosyal medya ile reklamcılık, tüketicilerin birbirleri ile etkileşime geçmelerini sağlayan geleneksel ağızdan ağıza pazarlamanın çok büyük oranda geliştirilmiş halidir. Diğer taraftan 
sosyal medyanın global erişim kapasitesine sahip olması, multimedya formatlarını içermesi, çok çeşitli platforma sahip olması da bu mecranın kullanımını işletmeler açısından çekici kılmaktadır (Güçdemir, 2017: 75).

Göktaş ve Tarakçı (2018: 64)'nın yapmış olduğu araştırmanın sonucuna göre, sosyal medyada reklâmların dikkat çekici olması ve diğer kullanıcılar tarafından paylaşılması, kullanıcıları o ürünü satın almaya itmekte ya da kullanıcılar söz konusu reklama ilişkin marka ve ürün hakkında daha fazla bilgi sağlamaya çalışmaktadırlar.

Teknolojik değişim, özellikle halkla ilişkiler penceresinden bakıldığında yapı, kültür ve kurum yönetimi için pek çok önemli göstergeler sunmaktadır. En önemli gösterge ise pek çok kuruluşun hiyerarşik doğasını değiştirmesidir (Güçdemir, 2017: 35). Grunig (2009: 1)'e göre yeni medya halkla ilişkiler mesleğini daha global, daha stratejik, çift yönlü, etkileşimli ve sosyal olarak daha sorumlu hale getirme potansiyeline sahiptir. Bu nedenle halkla ilişkiler, davranışsal ve stratejik bir yönetim paradigması olarak yeniden yapılandırılmalıdır.

Sosyal medyanın halkla ilişkiler kampanyalarında kullanımı günümüz koşullarında artık bir zorunluluk haline gelmiştir ama özellikle kaliteli üretim yapan, şeffaflık ilkeleriyle yönetilen ve yeni medya koşullarına ayak uydurabilen kurumlar için, halkla ilişkiler stratejilerinin geliştirilmesinde ve yaygınlaştırılmasında çeşitli avantajlar sağlamaktadır. Bu avantajlardan bazıları şunlardır (Biber, 2000: 164);

- Hedef pazarın daha büyük bir oranına, daha hızlı ulaşılabilir,

- Kurum kimliği, misyonu ve vizyonu geniş kitlelere daha hızlı aktarılır,

- Hedef kitlenin yönelimlerinin takibi daha kolay olur ve talebe göre halkla ilişkiler kampanyaları geliştirilebilir ya da esnetilebilir,

- Marka yaratılabilir, markanın daha geniş kitlelerce sahiplenilmesi sağlanabilir ve marka değeri yükseltilebilir,

- Hedef kitleye ürüne/hizmete, markaya ve işletmeye ilişkin bilgiler, eğitimler ya da yenilikler daha kısa sürede ve zamanında aktarılır,

- Halkla ilişkilerde, doğru stratejik adımların sosyal medyada doğru aktarılmasıyla kurum itibarı arttırılır ve bu itibarın sürdürülebilirliği sağlanabilir.

\section{TURIZM SEKTÖRÜ ve SOSYAL MEDYA}

Kullanıcı sayısı her geçen yıl katlanarak artan ve artık dünya nüfusunun yarısının kullanımına açılan sosyal medya, hemen hemen tüm sektörler için hedef kitleye ulaşmanın en hızlı ve daha az maliyetli yolu olmaktadır. Bu nedenle pazarlama kampanyalarının sosyal medya üzerinden yürütülmesi, reklam faaliyetlerinin sosyal medya platformlarındaki etkinliğinin düşünülerek geliştirilmesi, halkla ilişkiler kampanyalarının sosyal medyada paylaşılması ve geliştirilen stratejilerin sosyal medyayı da içermesi önem arz etmektedir.

Dijitalleşen dünyada her sektörde olduğu gibi turizm sektöründe de sosyal medya, işletme kararlarını etkileyen, pazarlama ve halkla ilişkiler stratejilerini şekillendiren önemli bir faktör haline gelmiştir. Turizm sektörünün kendine has özellikleri dikkate alındığında, turistlerin turizm destinasyonlarında yaşamış olduğu iyi ve kötü deneyimleri sosyal medya platformlarında paylaşması, diğer katılımcıların seçimlerini büyük oranda etkilediği söylenebilir. Ancak diğer taraftan turistik destinasyonlarda turizmin tüm paydaşları tarafından paylaşılan doğru ve etkili paylaşımlar da turizm tüketicilerini etkilemektedir. 


\section{Sosyal Medyanın Turist Kararları Üzerindeki Etkisi}

İnsanın sosyal bir varlık olduğu düşünüldüğünde, sosyal medya platformlarının birçok insana önemli bir altyapı sunduğu söylenebilir. Tatil yapılan yerin ya da yemek yenilen, içki içilen mekânın sosyal medya aracılığıyla konumunu paylaşmak, fotoğraflarını yayınlamak vb. davranışlar insanların kendilerini daha değerli, daha yüksek sosyal statüde gösterme çabalarının bir sonucu olarak değerlendirilebilir (Eryılmaz, 2014: 77). Sosyal medyada bu çabaların bir de alııı tarafı vardır. Bu paylaşımlar gerek özenti gerek merak gerek deneyimle isteği gibi sebeplerle diğer sosyal medya kullanıcılarını etkilemektedir. Diğer sosyal medya kullanıcıları kimi zaman sadece o destinasyon ya da turistik tesisle ilgili bilgi sağlamayı yeğlerken, kimisi de orayı deneyimleme kararı vererek satın alma eğilimi göstermektedir (Eryılmaz ve Şengül, 2016: 33).

Sosyal medyada bir turist için seyahat deneyimlerinin oluşum süreci üç aşamada gerçekleşmektedir. Bunlardan ilki, tercih edeceği yer hakkında daha önce o yere giden insanların paylaşımların etkisiyle seyahat kararı almasına etki eden geçmiş deneyimlerdir. İkincisi ise, seyahat ve konaklama sırasında oluşan gerçek zamanlı paylaşımlardan oluşan deneyimdir. Son olarak, Seyahat ve konaklama sonrası sosyal medya platformlarında yaptıkları yorumları, değerlendirmeleri ve ifade ettikleri duyguları içeren deneyimlerdir (Milano vd., 2011: 474).

Turizm aktivitesi içinde yer alan veya almayı planlayan kişiler, bu etkinlikler için daha fazla bilgi alabilecekleri sosyal ağlar aracılığıyla çevre ile bağlantı halinde olmaktadır. Ayrıca, bu tür alışverişlerin, ürün ve hizmetler hakkındaki yorumlar veya yorumları okumak için çaba gösteren potansiyel müşteriler üzerinde bir etkisi olması muhtemeldir (Aktan, 2018: 232). Günümüzde sadece seyahat kararı vermek için değil birçok alışveriş kararını vermede sosyal medyanın sunduğu imkânlardan (ürün hakkında tüketici yorumu, ürünün tüketici gözünden görseli vb.) dolayı tercih edilir ve sıklıkla kullanılır duruma gelmiştir.

\section{Turizm İşletmelerinde Sosyal Medya Kullanımının Önemi}

Sosyal medya kullanımı turizm sektörü için sadece turistlerle sınırlı değildir. Turizm işletmeleri de sosyal medya platformlarında içerik paylaşımı yapabilmekte ve tüketicilerin deneyimlerini kendi sayfalarında paylaşabilmektedirler. Sosyal medya sayesinde turizm işletmelerinin hedef kitlesi hem doğrudan doğruya işletmelerin ürettiği içeriğe ulaşabilmekte hem de deneyim sahibi kullanıcıların işletme ya da destinasyonla ilgili ürettikleri içeriklere ulaşabilmektedirler (Eryılmaz ve Zengin, 2014: 150).

Sosyal medyanın hem işletmelere hem de tüketicilere sağladığı kolaylıklardan ötürü, gerek işletmeler gerekse tüketiciler tarafından kullanımı ve kullanıcı sayısı ciddi bir şekilde hızla artmaktadır. Sosyal medya ile ilgili yapılan istatistiklere bakıldığında, 2010 yılında dünyada 1 milyara yakın sosyal medya kullanıcısı bulunurken bu rakamın 2018 yılında 2.62 milyara yükseldiği, 2020 yılının Ocak ayında ise 3.80 milyara yükseldiği görülmektedir (Datareportal1, 2020). Bu açıdan bakıldığında, dünya nüfusunun neredeyse yarısı sosyal medyayı kullanmaktadır ve turizm sektörü de insan odaklı bir sektördür. Turizm sektörünün, turist tercihlerinde önemli bir etki haline gelen sosyal medyayı göz ardı etmemesi elzem bir durumdur.

Doğrudan pazarlamanın son ulaştığı noktalardan biri olarak kabul edilen web pazarlaması (Kotler vd., 1999), günümüzde sosyal medya üzerinden yapılan pazarlama ile son noktaya ulaşmıştır. Sosyal medyanın mevcut potansiyelinin farkına varılması ile işletmelerin gündemine girmiş ve işletmeler tarafından sosyal medyaya dair stratejiler geliştirilmeye 
başlanmıştır (Aktan, 2018: 229). Fakat bir işletme sosyal medya ağlarının hangilerini veya hangisini kullanılırsa etkili bir strateji olur, bu da ayrı bir tartışma konusudur. Ama en azından hangi sosyal paylaşım sitesi ne işe yarar, onun hakkında bilgi sahibi olunması gerekmektedir. Turizm işletmelerinin, turizm ürünlerinin sunulduğu Tripadvisor, Booking gibi sosyal medya ağlarının kullanımı yanında, potansiyel tüketicilerin kullandıkları ve bilgi alabildikleri sosyal ağları da tespit ederek ona göre pazarlama stratejileri belirlemeleri gerekmektedir. Günümüzde Facebook, Instagram, Twitter, Linkedln, Youtube, Google+, Pinterest, Tumblr, Sanpchat, Periscope, Whatsapp, Swarm ve Flickr gibi birçok sosyal medya ağı mevcuttur (Sem Seo, 2019). İşletmelerin, sattıkları ürüne göre hangi sosyal medya ağlarını kullanacağına çok iyi karar vermeleri gerekmektedir. Klasik internet pazarlama yöntemlerinden siyrılarak daha aktif ve daha hızlı, her an takip edilebilen ve çift taraflı iletişime açık olduğu için hemen dönüt alınabilen yeni bir pazarlama sistemi, sosyal medya aracılığıyla sağlanabilmektedir (Çiftçi, 2016: 548).

Sosyal medya ile tüketiciler, kurumların sosyal medya hesapların beğenebilir, yorum yapabilir ve kendisi tarafından üretilen içerikleri paylaşarak diğerleri ile etkileşimde bulunabilirler. Böylece hem kurumlar için hem de hedef kitleler için avantaj ve yeni olanaklar sağlayacak olan, iki yönlü iletişimlere olanak veren bir yapıya erişilecek; aynı zamanda kulaktan kulağa pazarlama faaliyetlerinin yapılabileceği bir medya ortamı sağlanmış olacaktır (Aktan, 2018: 230).

Doğan vd. (2018: 674), Türkiye'yi tatil destinasyonu olarak tercih eden yabancı turistlerin karar alma süreçlerinde sosyal medyayı ne ölçüde kullandıkları ve sosyal medyadan elde ettikleri bilgilerden ne yönde etkilendiklerini araştırmış ve turistlerin tatil tercihlerinde sosyal medyanın etkili bir şekilde kullanmakta olduğunu ve sosyal medyadan edindikleri bilgilere göre tatil tercihlerinin tümünü belirlediklerini (destinasyon, konaklama, ulaşım ve restoran tercihleri) ya da seçimlerini sosyal medyadan edindikleri bilgilere göre değiştirdiklerini saptamışlardır.

Ancak sosyal medyanın birçok avantajı olmakla birlikte dezavantajları da mevcuttur. Sosyal medyadaki en büyük dezavantaj hızlı paylaşım nedeniyle olumsuz haberlerin çok çabuk yayılabilmesi ve işletmelerin bu durumu yönetebilmelerinin çok zor olmasıdır. Eğer bir işletme sosyal medya aracılığıyla yapılan eleştirilere ve sorunlara hızlı cevap veremezse, tüketiciler nezdinde işletmeye olan güven sarsılabilmektedir. Ayrıca, sosyal medyada üretilen bilgiler filtrelenmezse, kişiler aşırı bilgiye maruz bırakılmakta ve insanlar hangi kaynaktan ve hangi bilgilerden yararlanacakları konusunda sorun yaşamaktadır (Dirik, 2012: 51). Turistik tüketiciler aldıkları turistik ürün ve hizmetler hakkında sosyal medya paylaşım ve yorumları yapmaktadırlar. Bu nedenle turizm işletmelerinin olumlu veya olumsuz paylaşımları kontrol edebilmek açısından sosyal medyada aktif olmaları ve kendileri hakkında yapılan yorumlara göre müşteriler nezdindeki ve imajını belirleyerek o imajı yönetme çabalarında bulunabilirler.

Turizm aktivitelerinin etkinliği konusunda sosyal medya hem turizm işletmelerine hem turizm endüstrisine hem de turizm aktivitelerine katılan ya da katılmayı düşünen bireylere geniş imkânlar sağlamaktadır. Ancak endüstrisi bu imkânlardan daha fazla fayda sağlamak için çeşitli sosyal medya platformlarını daha kapsamlı ve daha geniş bir içerikle kullanmalıdır (Aktan ve Koçyiğit, 2016: 70).

İnternet ve sosyal medyanın en büyük gücü hızlı, ucuz ve kolay yoldan bilgi ve paylaşımı yapabilme özelliğidir. Fakat bu özellikler aynı zamanda sosyal medya ve internetin en büyük zayıflığıdır. Arama motorları, kullanıcıların trilyonlarca baytlık veriden ihtiyaç duydukları bir bilgi satırına hızlı ve kolay bir şekilde ulaşabilmelerine yardımcı olmaktadır (Qualman, 2011: 10). Özellikle turizm işletmeleri açsıdan sosyal medyada hızlı, ucuz ve kolay bir yoldan paylaşım yapılıyor olması turist tercihlerini hem olumlu hem de olumsuz etkilemektedir. 
Turizm işletmeleri için hızlı, kolay, ucuz ve sınırsız reklam ve tanıtım fırsatları sunmakla en büyük faydayı sağlamaktadır. Fakat sosyal medyadaki paylaşım hızı turistler nezdinde, turizm işletmelerinde yaşadıkları olumsuzlukları yansıtmaları açısından olumsuz bir etken olarak turizm işletmelerinin karşılarına çıkmaktadır.

\section{SONUÇ VE ÖNERİLER}

İnsanlar gündemi takip etmek ve güncel meseleler hakkında bilgi sahibi olabilmek amacıyla yeni iletişim teknolojilerini aktif bir biçimde kullanırken; ticari işletmelerin de yeni iletişim teknolojilerinin daha hızlı, pratik, az maliyet ve daha fazla hedef kitleye ulaşma gibi fırsat sunması nedeniyle internet ve sosyal ağların kullanımları her geçen gün daha da artmaktadır. Böylece sosyal medya uygulamaları, yeni iletişim teknolojilerinin sonucu olarak ortayla çıkmıştır.

Etkili ve verimli yönetilen sosyal medya uygulamaları sayesinde işletmeler; müşteri ilişkileri, satış geliştirme, reklam gibi faaliyetlerini düşük maliyetle daha geniş kitlelere iletebilmektedirler. Sosyal medyanın hem işletmelere hem de tüketicilere sağladığ kolaylıklardan ötürü gerek işletmeler gerekse tüketiciler tarafından kullanımı ve kullanıcı sayısı ciddi bir şekilde hızla artmaktadır.

Sosyal medya kullanan tüketiciler için çift taraflı bir etkileşim söz konusudur. Hem paylaşımlarıyla diğer sosyal medya kullanıcılarını etkilemekte hem de onlardan etkilenmektedirler. Tüketiciler bu durumda kimi zaman ürün ve hizmetler konusunda sadece bilgi sahibi olurken kimi zaman da satın alma karar verebilmektedir (Eryılmaz ve Şengül, 2016: 33). Özellikle turizm işletmeleri açsıdan sosyal medyada hızlı, ucuz ve kolay bir yoldan paylaşım yapilıyor olması, turist tercihlerini hem olumlu hem de olumsuz etkilemektedir. Turizm işletmeleri için hızlı, kolay, ucuz ve sınırsız reklam ve tanıtım fırsatları sunmakla en büyük faydayı sağlamaktadır. Ancak sosyal medyanın işletmeler açısından en büyük dezavantajı, hızlı paylaşım nedeniyle olumsuz haberlerin çok çabuk yayılabilmesi ve işletmelerin bu durumu yönetebilmelerinin çok zor olmasıdır. Eğer bir işletme sosyal medya aracılığıyla yapılan eleştirilere ve sorunlara hızlı cevap veremezlerse tüketiciler nezdinde işletmeye olan güven sarsılabilmektedir. Bu nedenle sosyal medya pazarlamasına yönelik stratejiler geliştirilmesi ve uygulanması gerekmektedir.

Sonuç olarak, turizm işletmeleri sosyal medya kanalları üzerinden kendi topluluklarını oluşturup, oluşturduğu topluluğu iyi yönetebilirse amaçladıkları hedefe ulaşabilir. Sosyal medya araçları üzerindeki topluluklar, sosyal ağlar, multimedya paylaşım, profesyonel ağlar, bloglar, forumlar, mikro bloglar, anlık mesajlaşma ortamları, şikâyet ve öneri paylaşım ortamları oluşturabilirler. Çeşitli iletişim kampanyaları ile bu platformlar üzerinden iletişimi sürekli kılıp, kullanıcılara aktif olarak cevap verebilirler.

Ayrıca turizm destinasyonları, pazarlama ve tanıtım ile ilgili yapacakları tüm etkinliklerini sosyal medya üzerinden uygulayacakları doğru yöntem ile kısa sürede hedef kitlesinin çoğu üzerinde sürdürebilme olanağına sahiptir. Destinasyonların tanıtımının doğru yapılabilmesi için, yetkili birimlerce turizm paydaşları tarafından yapılan paylaşımlar denetlenmeli ve kurumların, ürünlerin ya da işletmelerin doğru olmayan ifadelere karşı denetimi sağlanmalıdır. Destinasyonla ilgili bilgi akışı sürekli güncellenmeli ve tanıtım-pazarlama faaliyetlerinin kontrol altında olmasına hassasiyet gösterilmelidir. Destinasyonda bulunan turizm işletmelerinin, sık kullanılan sosyal medya platformlarında kurumsal kimlikleriyle bulunması ve sayfalarında güncel ve doğru bilgileri paylaşmaları sağlanmalıdır. Turizm paydaşları (kurumlar, işletme sahipleri, esnaflar, çalışanlar, sivil toplum kuruluşları vb.) sosyal medya 
kullanımı konusunda bilgilendirilmelidir. Diğer taraftan eğitim kurumlarının müfredatlarındaki derslere sosyal medya kullanımına yönelik konuların ilave edilmesinin de faydalı olabileceği değerlendirilmektedir. Böylelikle hem pazarlamanın en güçlü araçlarından biri haline gelen sosyal medyanın eğitimli bireyler tarafından kullanımı sağlanmış olacak hem de destinasyon tanıtımı daha geniş kitlelere doğru şekilde yapılacaktır.

Yaş, internet ve sosyal medya kullanım süresi gibi konuların kuşaklararası değişimler göz önüne alınarak çalışılmasının, turizm sektöründe sosyal medya kullanımına yönelik akademik literatüre katkı sağlayabileceği değerlendirilmektedir.

\section{KAYNAKÇA}

Akar, E. (2010). Sosyal Medya Pazarlaması. Ankara: Eflatun Basım Dağıtım Yayıncllık.

Akıncı Vural, Z. B., ve Bat, M. (2010). Yeni Bir İletişim Ortamı Olarak Sosyal Medya: Ege Üniversitesi İletişim Fakültesine Yönelik Bir Araştırma, Journal of Yasar University, 20(5): 3348-3382.

Aktan, E. (2018). Sosyal Medyanın Turizm Pazarlamasındaki Rolünün Değerlendirilmesi. Journal of Tourism and Gastronomy Studies, 6 (3): 228-248.

Aktan, E., ve Koçyiğit, M. (2016). Sosyal Medya'nın Turizm Faaliyetlerindeki Rolü Üzerine Teorik Bir İnceleme. Sosyal Bilgiler Dergisi ICEBSS Özel Sayısı: 62-73.

Bulunmaz, B. (2014). Yeni Medya Eski Medyaya Karşı: Savaşı Kim Kazandı ya da Kim Kazanacak?. Karadeniz Teknik Üniversitesi İletişim Araştırmaları Dergisi, 4(1): $22-29$

Cote, M. and Pybus J. (2007). Learning to Immaterial Labour 2.0: MySpace and Social Networks. Ephemera Articles, 7 (1): 88-106.

Çalışkan, M. ve Mencik, Y. (2015). Değişen Dünyanın Yeni Yüzü: Sosyal Medya. Akademik Bakış Dergisi, 50: 254-277.

Çiftçi, H. (2016). Turistik Destinasyon Ürünlerinin Popülerleşmesinde Sosyal Medyanın Rolü. Akademik Sosyal Araştırmalar Dergisi, 33: 544-551.

Datareportal. (2020). Digital 2020: Global Digital Overview. <https://www.kisa.link/N3> [Erişim Tarihi: 17.03.2020].

Datareportal2. (2020). Digital 2020: Turkey. < https://www.kisa.link/N3bI> [Erişim tarihi: 18.03.2020].

Dirik, N. (2012). Sosyal Medyada Destinasyon Tanıtımı, Yayınlanmamış Uzmanlık Tezi, Kültür ve Turizm Bakanlığı Tanıtma Genel Müdürlüğü, Ankara.

Doğan , M., Pekiner , B., ve Karaca , E. (2018). Sosyal Medyanın Turizm ve Turist Tercihlerine Etkisi: Kars-Doğu Ekspresi Örneği. Seyahat ve Otel İşletmeciliği Dergisi, 15 (3): 669-683.

Erdoğan, İ. (2013). Dördüncü Güç Medyadan Beşinci Güç İnternete: Demokratik Bir Dönüşüm mü Yaşanıyor?, Selçuk İletişim Dergisi, 8 (1): 176-191.

Eryılmaz, B., ve Şengül, S. (2016). Sosyal Medyada Paylaşılan Yöresel Yemek Fotoğraflarının 
Turistlerin Seyehat Tercihleri Üzerine Etkisi. Uluslararası Türk Dünyası Turizm Araştırmaları Dergisi, 1 (1): 32-42.

Eryılmaz , B., ve Zengin , B. (2014). Sosyal Medyada Konaklama İşletmelerine Yönelik Tüketici Yaklaşımları Üzerine Bir Araştırma. İşletme Bilimi Dergisi, 2(1): 147-167.

Eryılmaz, B. (2014). Sosyal Medya Kullanımının Müşteri Tercihleri Üzerine Etkileri: Konaklama İşletmelerinde Bir İnceleme, Yayınlanmamış Doktora Tezi, Sakarya Üniversitesi, Sakarya.

Felix, R., Rauschnabel, P. A., and Hinsch, C. (2017). Elements of Strategic Social Media Marketing: A Holistic Framework. Journal of Business Research, 70: 118-126.

Göktaş, B. ve Tarakçı, İ. E. (2018). Bir Tutundurma Aracı Olarak Reklamın Sosyal Medyada Uygulamalarına Yönelik Bir Araştırma: Instagram Örneği. Girişimcilik İnovasyon ve Pazarlama Araştırmaları Dergisi, 2(3):50-67.

Grunig, J. E. (2009). Paradigms of Global Public Relations in An Age of Digitalization, Prism, 6(2): 1-19.

Güçdemir, Y. (2017). Sosyal Medya, Halkla İlişkiler, Reklam ve Pazarlama. İstanbul: Der Kitabevi ve Yayıncilik.

Királová, A. and Pavlíčeka A. (2015). Development of Social Media Strategies in Tourism Destination. Procedia - Social and Behavioral Sciences, 175: 358 - 366.

Kırık, A. M. (2017). Yeni Medya Aracılığıyla Değişen İletişim Süreci: Sosyal Paylaşım Ağlarında Gençlerin Konumu. Gümüşhane Üniversitesi İletişim Fakültesi Elektronik Dergisi, 5 (1): 230-261.

Kotler, P., Bowen , J., and Makes, J. C. (1999). Marketing for Hospitality and Tourism. New Jersey: Prentice Hall.

Milano, R., Baggio, R., and Piattelli, R. (2011). The Effects of Online Social Media on Tourism Websites. 18th International Conference on Information, Technology and Travel \& Tourism, 26-28 January 2011, Innsbruck, Austria.

O'Brien, K. and Terschluse, C. (2009). Degerming the Impact of Customer Relationships Social Media Measurement $\mathcal{E}$ Analysis, Los Altos: Crimson Consulting Group.

Özgen, E. ve Doymuş, H. (2013). Sosyal Medya Pazarlamasında Farklılaştırıcı Bir Unsur Olarak İçerik Yönetimi Konusuna İletişimsel Bir Yaklaşım, Online Academic Journal of Information Technology, 4 (11): 91-103.

Özgen, E. (2011). Halkla İlişkiler ve Yeni Medyanın İşaret Ettiği Sorunlar Üzerine Bir Tartışma, Global Media Journal Turkish Edition, 1(2): 84-105.

Pfetsch, B., Adam, S. and Bennett, W. L. (2013). The Critical Linkage Between Online and Offline Media - An Approach to Researching the Conditions of Issue Spill-Over, Javnost- The Public Journal of the European Institute for Communication and Culture, 20 (3): 9- 22.

Qualman, E. (2011). Socialnomics: How Social Media Transforms the Way We Live and Do Business, New Jersey: John Wiley \& Sons.

Sabuncuoğlu, Z., ve Gümüş, M. (2008). Örgütlerde Iletişim. Ankara: Arıkan Basım Yayım 


\section{Dağıtım.}

Sayımer, İ. (2008). Sanal Ortamda Halkla Ilişkiler. İstanbul: Beta Yayıncllık.

Scott, D. M. (2010). The New Rules of Marketing and PR. New Jersey: John Wiley \& Sons, Inc.

Sem Seo. (2019). Sosyal Medya Ağları Nelerdir?, https://www.semseo.com.tr/sosyal-medya-aglarinelerdir.html> [Erişim Tarihi: 29.03.2019].

Tekvar, S. O. (2012). Yeni Medya ve Kurumsal Kültür: Avrupa ve Türkiye'deki Farklı Kurumsal Yapıların Karşılaştırması, Atılım Sosyal Bilimler Dergisi, 2 (1): 81-103.

Tiryaki, S. (2015). Sosyal Medya ve Facebook Bağımlılı̆̆ı. Konya: Sebat Ofset ve Matbaacılık.

Törenli N. (2005). Yeni Medya, Yeni İletişim Ortamı, Bilim ve Sanat Yayınları, Ankara'dan aktaran Balcı, Ş., Arsal Gölcü, A. ve Eray Öcalan, M. (2013) Üniversite Öğrencileri Arasında İnternet Kullanım Örüntüleri, Selçuk İletişim Dergisi, 7(4): 5-22.

TUIK. (2020). Bilgi Toplumu İstatistikleri, 2004-2019, <https://www.kisa.link/N2Bk>, [Erişim Tarihi: 16.03.2020].

Vardarlier, P. (2016). Sosyal Medya Stratejisi. Ankara: Nobel Akademik Yayıncılık.

Varol, S. F. (2017). Medyanın Küreselleşmesi: Neden-Sonuç Ekseninde Bir Değerlendirme, Gümüşhane Üniversitesi İletişim Fakültesi Dergisi, 5(1): 399-424.

WPR 1 (World Population Review). (2020). World Population Estimator, $<$ https://worldpopulationreview.com/>, [Erişim Tarihi: 18.03.2020].

$\mathrm{WPR}_{2}$ (World Population Review). (2020). Turkey Population Estimator, $<$ https://www.kisa.link/N359>, [Erişim Tarihi: 18.03.2020].

www.dijitalpazarlamaokulu.com. (2020). Geleneksel Pazarlama ile Dijital Pazarlama Arasındaki 10 Fark, <https://www.kisa.link/N3E5> [Erişim Tarihi: 16.03.2020].

www.cdn-acikogretim.istanbul.edu.tr. (2020). Halkla İlişkilerde Sosyal Medya Yönetimi, https://www.kisa.link/N6s [Erişim Tarihi: 17.03.2020]. 